\title{
Phosphorus Speciation in Sludge from Nickel Electroplating
}

\author{
Takashi Fujimori ${ }^{1,2, *}$, Hideo Hayashi ${ }^{3}$ and Kenichi Nakajima ${ }^{4}$ \\ ${ }^{1}$ Department of Global Ecology, Graduate School of Global Environmental Studies, Kyoto University, Kyoto 615-8540, Japan \\ ${ }^{2}$ Department of Environmental Engineering, Graduate School of Engineering, Kyoto University, Kyoto 615-8540, Japan \\ ${ }^{3}$ Tokyo Metropolitan Industrial Technology Research Institute, Tokyo 144-0035, Japan \\ ${ }^{4}$ Center for Material Cycles and Waste Management Research, National Institute for Environmental Studies (NIES), \\ Tsukuba 305-8506, Japan
}

The recycling of secondary resources to close material cycle loops should reduce the consumption of natural resources and thus help to reduce the environmental impact. For recycling, it is crucial to consider not only the nickel (Ni) content in the secondary resources, such as $\mathrm{Ni}$ plating waste liquids and sludge, but also the impurity levels, particularly the phosphorus $(\mathrm{P})$ concentration. This study characterized the $\mathrm{P}$ species in three sludges from $\mathrm{Ni}$ electroplating processes using $\mathrm{P} \mathrm{K}$-edge X-ray absorption near-edge structure (XANES) spectroscopy. The Ni and P concentrations in the sludges ranged from 11 to $41 \%$ and 2,800 to $24,000 \mathrm{ppm}$, respectively, depending on the type of sludge. The $\mathrm{P}$ $\mathrm{K}$-edge XANES analysis identified phosphates and organic $\mathrm{P}$ as the major $\mathrm{P}$ species in the sludges, and hypophosphite and phosphite species as minor species. These findings provide detailed knowledge that should help to control P in Ni electroplating sludge.

[doi:10.2320/matertrans.M2017152]

(Received May 12, 2017; Accepted June 13, 2017; Published July 14, 2017)

Keywords: nickel electroplating, sludge, phosphorous, speciation, X-ray absorption near-edge structure

\section{Introduction}

Materials that contain nickel (Ni) are becoming increasingly useful because of their physical and other properties; however, the demand for $\mathrm{Ni}$ and other metal resources has grown rapidly and there have been reports of environmental problems accompanying its extraction and refining. ${ }^{1,2)}$ Studies have examined the impact of extraction and refining on the loss of animal and plant habitat, ${ }^{3)}$ as well as on biodiversity, ${ }^{4)}$ and there have been case reports from Ni ore- and ferronickel/Ni metal-producing countries of encroachment on nature protection zones, ${ }^{5)}$ inappropriate environmental management at production facilities accompanied by heavy metal pollution, ${ }^{6,7)}$ and emissions, including sulfur oxides and mining waste. ${ }^{8)}$ The production of substances such as ferronickel requires large amounts of energy and many greenhouse gases are emitted. ${ }^{9,10)}$

Recycling secondary resources to close the loop in the material cycle should reduce the consumption of natural resources and thus contribute to reducing the environmental impact. For recycling, it is critical to consider not only the $\mathrm{Ni}$ content in secondary resources, such as Ni plating waste liquids and sludge, but also the impurity level, particularly the phosphorus (P) concentration. Phosphorus is normally considered an undesirable impurity in steel production because it has detrimental effects on the mechanical properties of steel. The market typically requires that the $\mathrm{P}$ content of ferronickel be less than $0.02 \% .^{11)}$

Waste water from Ni plating contains high concentrations of $\mathrm{Ni}$ and $\mathrm{P}^{12)}$ This waste water is treated by oxidization, neutralization, and settling, and is finally separated into solid and liquid phases. The residual solid phase, called sludge, contains Ni and P. Recently, several technologies have been developed for recycling $\mathrm{Ni}$ and $\mathrm{P}$ removal from waste water from Ni plating. ${ }^{13)}$ Phosphorous speciation might influence

*Corresponding author, E-mail: fujimori.takashi.3e@kyoto-u.ac.jp to improve understanding of the P removal technology from the sludge. However, basic information on the $\mathrm{P}$ species in sludge has not been reported because they are found in lower concentrations than other main elements, such as $\mathrm{Ni}$.

Phosphorus K-edge X-ray absorption near-edge structure (XANES) spectroscopy is a nondestructive, element-selective method for identifying low-concentration $\mathrm{P}$ species in a complex matrix and can distinguish inorganic and organic forms. ${ }^{14)}$ Recently, P K-edge XANES spectroscopy has been applied to environmental samples, such as marine sediment, ${ }^{14)}$ minerals, ${ }^{15)}$ soil, ${ }^{16)}$ and poultry litter. ${ }^{17)} \mathrm{P}$ K-edge XANES spectroscopy of the sludge from Ni electroplating should produce new insights into the $\mathrm{P}$ species in sludge and help control P levels in waste.

In this study, we characterized the $\mathrm{P}$ species in sludges from Ni electroplating using $\mathrm{P}$ K-edge XANES spectroscopy and quantified the elements in sludge samples.

\section{Experimental Procedure}

\subsection{Sludge samples from plating processes}

Three sludge samples were collected from industrial plating sites in Japan. Sludge A was sampled as dewatered cake from a settling tank after several treatments with Ni electroplating solution. This sludge had been treated by (i) washing with water, (ii) adjusting the $\mathrm{pH}$ to 3 , (iii) mixing with other water discharged from defatting and acid-washing processes, (iv) precipitation by adjusting the $\mathrm{pH}$ to 10 , (v) agglomeration, and (vi) settling. Sludge B was sampled as dewatered cake from a settling tank after electroplating processes involving several metals, including $\mathrm{Ni}$, chromium, and copper. Sludge $C$ was sampled from a mixing tank containing waste water from several electroplating processes before the precipitation process.

Many chemicals are used in the treatment of wastewater from $\mathrm{Ni}$ electroplating, including hydrosulfate, ferric chloride $\left(\mathrm{FeCl}_{2}\right)$, caustic soda $(\mathrm{NaOH})$, lime hydrate $\left[\mathrm{Ca}(\mathrm{OH})_{2}\right]$, 
polymer coagulant, and defatting agents. In this study, we divided the sludge samples into two types: "separate" and "mixed". "Separate" referred to sludge collected only from $\mathrm{Ni}$ electroplating processes. "Mixed" indicated sludge collected from several plating processes. Sludge A was separate type and sludges $\mathrm{B}$ and $\mathrm{C}$ were mixed type (Table 1 ).

\subsection{Quantification of elements in sludge samples}

The concentrations of elements in the sludge samples were quantified on a dry basis in instrumental analyses. We measured the moisture content of the sludge samples after drying the samples at $110^{\circ} \mathrm{C}$ for 2 hours. The moisture content was defined as the percentage decrease in the original weight according to the Ministry of Environment Notification No.13 (Japan) standard.

We measured concentrations of elements after drying of sludges. The $\mathrm{P}$ and $\mathrm{Ni}$ in sludges $\mathrm{A}$ and $\mathrm{B}$ were measured using inductively coupled plasma atomic emission spectrometry (ICP-AES: ICPE-9000; Shimadzu, Kyoto, Japan) after acid digestion of the sludges with nitric acid $\left(\mathrm{HNO}_{3}\right)$. When $\mathrm{HNO}_{3}$ was insufficient for the digestion, sulfuric acid $\left(\mathrm{H}_{2} \mathrm{SO}_{4}\right)$ and hydrochloric acid $(\mathrm{HCl})$ were added and heated at an appropriate temperature on a hotplate.

Using wave-dispersive $\mathrm{X}$-ray fluorescence (WDXRF) (XRF-1800; Shimadzu), the P, Ni, calcium (Ca), and magnesium $(\mathrm{Mg})$ in sludges $\mathrm{A}$ to $\mathrm{C}$ were measured using a fundamental parameter method in a vacuum after making a sample disk.

The carbon contents of sludges $\mathrm{A}$ to $\mathrm{C}$ were quantified using a carbon/sulfur analysis instrument (CS-230SP; LECO, St. Joseph, MI, USA), which comprises a high-frequency induction heating furnace and infrared absorption analysis instrument. For this, a 0.1 0.2-g sludge sample was placed in a ceramic crucible. A mixture of powdered iron $(0.8 \mathrm{~g})$, tin $(0.3 \mathrm{~g})$, and tungsten $(0.7 \mathrm{~g})$ was used as an accelerator. An iron ore tailings sample (C: $1.88 \pm 0.04 \%$ ) was used as a standard sample, and the calibration curve for carbon (range: $0-120 \mathrm{mg})$ showed good linearity $\left(R^{2}>0.99\right)$.

\subsection{P K-edge X-ray absorption near edge structure (XANES) spectroscopy}

We performed $\mathrm{P}$ K-edge XANES measurement of the dried sludge samples at the beamline BL-11B, Photon Factory (Tsukuba, Japan). Powdered sludge samples were mounted on carbon tape and the P K-edge XANES spectra were collected in total fluorescence yield (TFY) mode in a

Table 1 Concentrations of the elements (dry basis) found in Ni electroplating sludge.

\begin{tabular}{lllr}
\hline & Sludge A & Sludge B & \multicolumn{1}{l}{ Sludge C } \\
\hline Separate or mix & Separate & Mixed & Mixed \\
Sampling point & Settling tank & Settling tank & Mixing tank \\
Moisture content $(\%)$ & 84 & 79 & 77 \\
P (ppm) & 2800 & 6100 & 24000 \\
Ni (\%) & 41 & 11 & 11 \\
$\mathrm{Ca}(\mathrm{ppm})$ & 3900 & 7500 & 92000 \\
$\mathrm{Mg}(\mathrm{ppm})$ & 85000 & 84000 & 8500 \\
$\mathrm{C}(\%)$ & 1.9 & 8.8 & 4.8 \\
\hline
\end{tabular}

vacuum, with $2140-2180 \mathrm{eV}$ as the P K-edge energy range. The XANES spectra of $\mathrm{P}$ in different inorganic and organic reference compounds were collected to identify the chemical state of $\mathrm{P}$. The inorganic $\mathrm{P}$ references were hydroxylapatite [HAP; $\left.\mathrm{Ca}_{5}\left(\mathrm{PO}_{4}\right)_{3} \mathrm{OH}\right]$, octacalcium phosphate [OCP, $\left.\mathrm{Ca}_{8} \mathrm{H}_{2}\left(\mathrm{PO}_{4}\right)_{6} \cdot 5 \mathrm{H}_{2} \mathrm{O}\right]$, dicalcium phosphate dehydrate $\left(\mathrm{DCPA}, \mathrm{CaHPO}_{4} \cdot 2 \mathrm{H}_{2} \mathrm{O}\right)$, beta-calcium phosphate $[\beta$ $\left.\mathrm{Ca}_{3}\left(\mathrm{PO}_{4}\right)_{2}\right]$, calcium phosphite monohydrate $\left(\mathrm{CaHPO}_{3}\right.$. $\left.\mathrm{H}_{2} \mathrm{O}\right)$, calcium hypophosphite $\left[\mathrm{Ca}\left(\mathrm{H}_{2} \mathrm{PO}_{2}\right)_{2}\right]$, newberyite $\left(\mathrm{MgHPO}_{4} \cdot 3 \mathrm{H}_{2} \mathrm{O}\right)$, sodium phosphate dodecahydrate $\left(\mathrm{Na}_{3} \mathrm{PO}_{4} \cdot 12 \mathrm{H}_{2} \mathrm{O}\right)$, and polyphosphate sodium $\left(\mathrm{Na}\right.$-polyPO $\left.\mathrm{PO}_{4}\right)$. The organic $\mathrm{P}$ references were triphenyl phosphate (TPP) and adenosine triphosphate disodium (ATP-Na $)_{2}$. These organic references involve the bonding of $\mathrm{P}$ with organic structures.

We used linear combination fitting (LCF) of XANES spectra to determine the major species using REX 2000 software (ver. 2.5.5; Rigaku, Tokyo, Japan). The linear combination fit for the experimental spectra was calculated using the residual value with the following formula:

$$
R=\frac{\sum\left(\mathrm{XANES}_{\text {measured }}-\mathrm{XANES}_{\text {calculated }}\right)^{2}}{\sum\left(\mathrm{XANES}_{\text {measured }}\right)^{2}} .
$$

\section{Results and Discussions}

\subsection{Elemental compositions of sludges}

The concentrations of the elements (dry base) in the sludge samples from Ni electroplating are shown in Table 1. Sludges A, B, and C had P concentrations of 2,800, 6,100, and 24,000 ppm, respectively. The $\mathrm{P}$ concentration in sludge $\mathrm{C}$ from the mixing tank was one order of magnitude higher than that in sludges $\mathrm{A}$ and $\mathrm{B}$. The Ni concentration in sludge A $(41 \%)$ was higher than that in the two mixed sludges $(11 \%) . \mathrm{Ca}, \mathrm{Mg}$, and $\mathrm{C}$ were found in all sludges because these elements are generally used as additives in the Ni electroplating process. Carbon contents (1.9-8.8\%) were enough to react with $\mathrm{P}$ by quantitative measurement (Table 1 ).

\subsection{Phosphorus speciation in sludges}

Two major $\mathrm{P}$ species, i.e., phosphates and organic phosphorous, were identified by analyzing the P K-edge XANES spectra of the sludge samples (Fig. 1). The post-edge structure of P K-edge can be used as a fingerprint region to identify the chemical condition of $\mathrm{P}$.

The post-edge dip structure of sludge A at 2,154 eV was similar to that of organic $\mathrm{P}$ and $\mathrm{MgHPO}_{4} \cdot 3 \mathrm{H}_{2} \mathrm{O}$, as shown by label ' $\mathrm{a}$ ' in Fig. 1. LCF identified the major $\mathrm{P}$ species in sludge $\mathrm{A}$ as $55 \%$ organic phosphorous and 32\% $\mathrm{MgHPO}_{4}$. $3 \mathrm{H}_{2} \mathrm{O}$ (Table 2). This suggests that the $\mathrm{P}$ in sludge $\mathrm{A}$ was mainly bonded to organics and $\mathrm{Mg}$. A minor proportion of the P $(13 \%)$ was identified as HAP.

The P K-edge XANES spectrum of sludge B was similar to that of sludge A, and LCF indicated that organic P (47\%) and $\mathrm{MgHPO}_{4} \cdot 3 \mathrm{H}_{2} \mathrm{O}(25 \%)$ were the dominant species (Table 2). Sludges A and B were collected from the same Ni-P plating facility, but were of different sample types ("separate" and "mixed", respectively). This suggests that the major $\mathrm{P}$ species were not influenced by mixing with other dis- 
charged water and deposits. Minor $\mathrm{P}$ species identified in sludge $\mathrm{B}$ were $\mathrm{HAP}$ and $\beta-\mathrm{Ca}_{3}\left(\mathrm{PO}_{4}\right)_{2}$ (Table 2).

Sludge $\mathrm{C}$ had a characteristic shoulder at $2,154 \mathrm{eV}$, which was derived from $\mathrm{Ca}$ phosphates such as $\beta-\mathrm{Ca}_{3}\left(\mathrm{PO}_{4}\right)_{2}$ and OCP ('b' in Fig. 1). The specific shoulder derived from $\mathrm{Ca}$ phosphates has been reported in P K-edge XANES spectroscopy studies using various $\mathrm{P}$ compounds. ${ }^{13,14)}$ In addition, a small and broad peak around $2,162 \mathrm{eV}$ was also seen for sludge $\mathrm{C}$. This peak was similar to the peaks of $\beta-\mathrm{Ca}_{3}\left(\mathrm{PO}_{4}\right)_{2}$

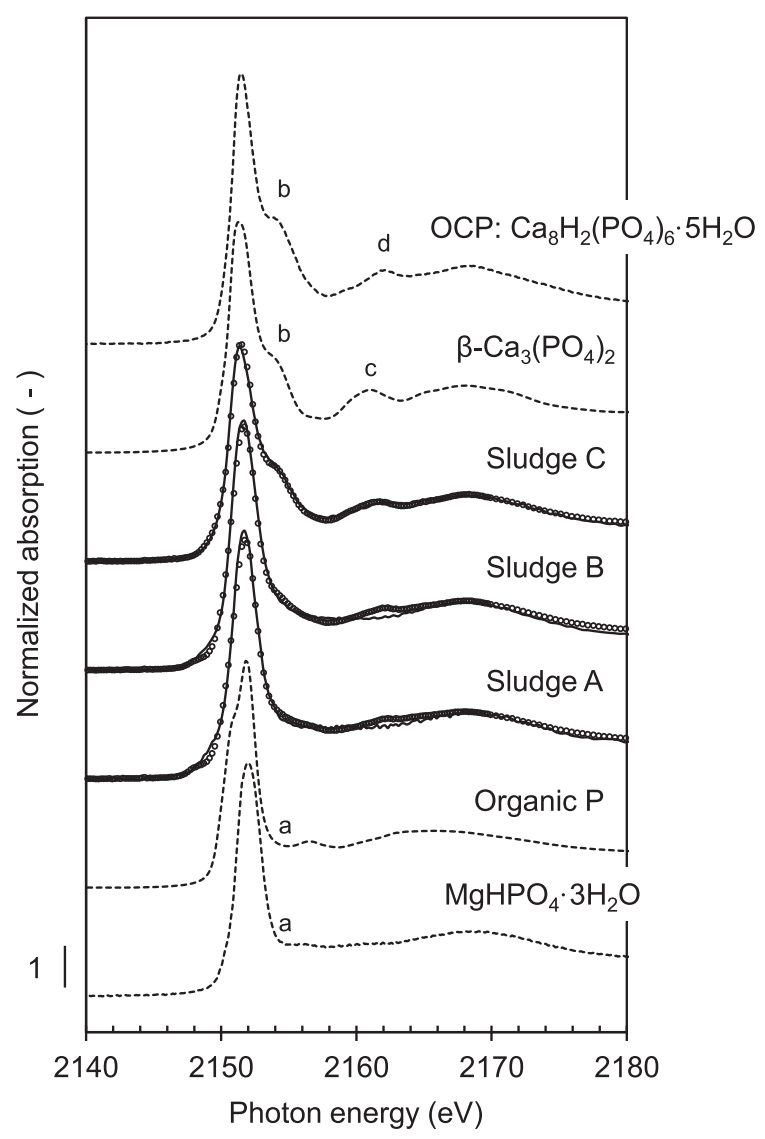

Fig. 1 Normalized $\mathrm{P}$ K-edge X-ray absorption near-edge structure (XANES) spectra of the sludge from nickel (Ni) electroplating: solid line, measured spectrum of the sludge sample; dashed line, spectrum of the standard material; circle, spectrum fitted using linear combination fitting. and OCP ('c' and 'd' in Fig. 1, respectively). According to the LCF, Ca phosphates comprised $75 \%$ of the $\mathrm{P}$ chemical form and were the main $\mathrm{P}$ species in sludge $\mathrm{C}$ (Table 2).

The spectrum edge around $2,150 \mathrm{eV}$ for the sludge samples had a broader shoulder than that of the phosphates and organic P, as shown in Fig. 1, implying the existence of other $\mathrm{P}$ species. Since the broader spectrum edge around $2,150 \mathrm{eV}$ was partly derived from $\mathrm{Ca}\left(\mathrm{H}_{2} \mathrm{PO}_{2}\right)_{2}$, a minor part of the $\mathrm{P}$ in sludges $\mathrm{A}$ and $\mathrm{B}$ existed as hypophosphite salts (Table 2). The edge structure of sludge $C$ was distinct from that of the other sludges and showed a fit with phosphite salts, such as Ca phosphite monohydrate (Table 2).

In addition, a fairly broad peak at 2,164 2,176 eV was found in sludges A and B. This broad peak pattern has been reported for several organic $\mathrm{P}$ compounds. ${ }^{14)}$ Phospholipid has a similarly broad structure. Organic residues were generally generated in the defatting process and mixed into the sludge. Therefore, phospholipid could form in the sludge phase.

It is noted that sampling point might influence to generate organic $\mathrm{P}$ species. Although all sludges contained carbon, organic $\mathrm{P}$ species were only identified in sludges $\mathrm{A}$ and $\mathrm{B}$ sampled from settling tank (Tables 1 and 2). However, organic $\mathrm{P}$ species were not identified in sludge $\mathrm{C}$ from mixing tank. Therefore, organic $\mathrm{P}$ species might generate in final residue from settling tank.

\section{Conclusion}

The $\mathrm{P}$ species in three sludges from Ni electroplating processes were characterized using $\mathrm{P}$ K-edge XANES spectroscopy. The $\mathrm{Ni}$ and $\mathrm{P}$ concentrations in the sludges ranged from $11-41 \%$ and 2,800-24,000 ppm, respectively, depending on the type (separate or mixed) and sampling point (settling or mixing tanks) of the sludge. Two major $\mathrm{P}$ species (phosphates and organic phosphorous) were identified in the sludges. Hypophosphite and phosphite species were identified as minor $\mathrm{P}$ forms. These detailed findings will help to improve the control of $\mathrm{P}$ in sludge from Ni electroplating.

\section{Acknowledgments}

We thank several companies for collecting sludge samples

Table 2 Phosphorus speciation of sludge from Ni electroplating determined by linear combination fitting of the P K-edge XANES spectra.

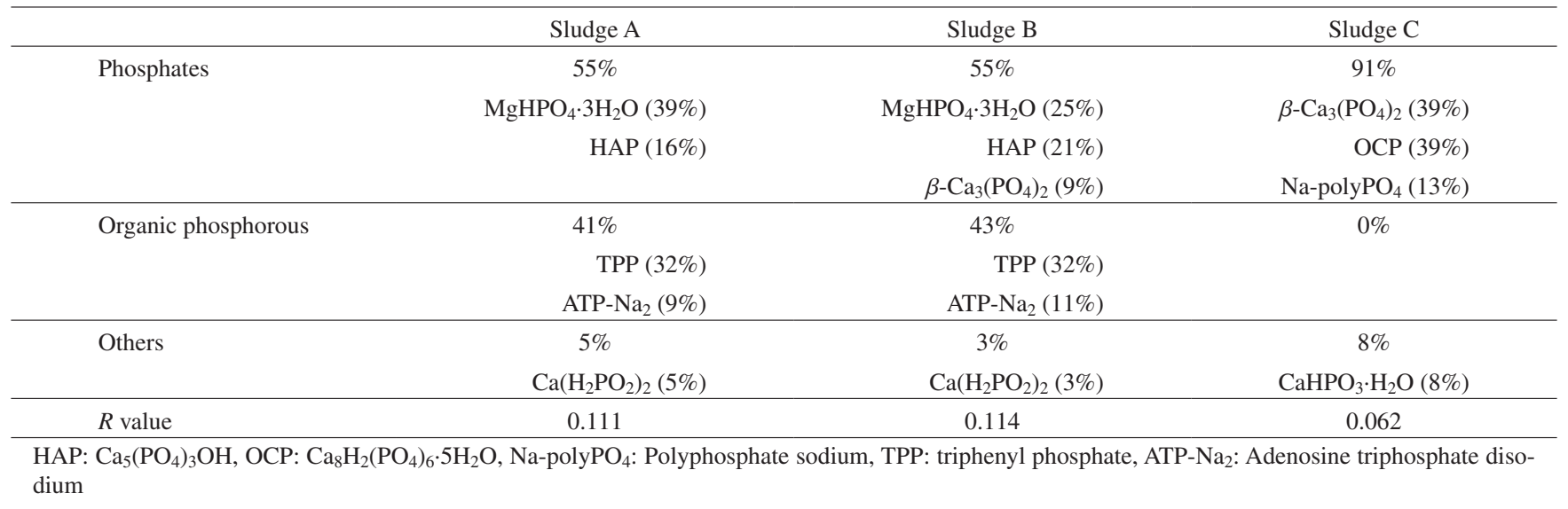


from plating processes; Prof. Masaki Takaoka, Mr. Kenji Shiota (Kyoto Univ.), and Dr. Yoshinori Kitajima (KEK) for support with $\mathrm{P}$ K-edge XANES measurements were performed at BL-11B, Photon Factory (Proposal 2016G021); Prof. Yohey Hashimoto (Tokyo Univ. of Agriculture and Technology) for providing specific standard spectra of $\mathrm{P}$ K-edge XANES; and Mr. Kenji Shiota for WDXRF measurement. The authors greatly acknowledge the financial support by a Grand-in-Aid for Scientific Research (B) from JSPS, Japan (No. 26281059 and No. 15H02862).

\section{REFERENCES}

1) K. Nakajima, Y. Otsuka, Y. Iwatsuki, K. Nansai, H. Yamano, K. Matsubae, S. Murakami and T. Nagasaka: Metall. Res. Technol. 111 (2014) 339-346.

2) K. Nakajima, K. Nansai, K. Matsubae, M. Tomita, W. Takayanagi and T. Nagasaka: Sci. Total Environ. 586 (2017) 730-737.

3) L. L'Huillier, T. Jaffré and A. Wulef: Mines et Environnement en Nouvelle-Calédonie: les milieu sur substrats ultramafiques et leur restauration, IAC, (2010) p.21.

4) D. Moran, M. Petersone and F. Verones: Ecol. Indic. 60 (2016) 192
201.

5) A.P. Durán, J. Rauch and K.J. Gaston: Biol. Conserv. 160 (2013) 272 278.

6) T. Norseth: Sci. Total Environ. 148 (1994) 103-108.

7) K. Bačeva, T. Stafilov, R. Šajn and C. Tănăselia: J. Environ. Sci. Health Part A-Toxic/Hazard. Subst. Environ. Eng. 47 (2012) 645-656.

8) G.A. Crawford: J. Geochem. Explor. 52 (1995) 267-284.

9) G.M. Mudd: Ore Geol. Rev. 38 (2010) 9-26.

10) M.J. Eckelman: Resour. Conserv. Recycling 54 (2010) 256-266.

11) F. K. Crundwell, M. S. Moats, V. Ramachandran, T. G. Robinson and W. G. Davnickelort: Extractive metallurgy of nickel, cobalt and platinum-group metals. Elsevier, (2011) p.85.

12) J. Sudagar, J. Lian and W. Sha: J. Alloy. Compd. 571 (2013) 183-204.

13) L. Li, N. Takahashi, K. Kaneko, T. Shimizu and T. Takarada: Separ. Purif. Tech. 147 (2015) 237-244.

14) J.A. Brandes, E. Ingall and D. Paterson: Mar. Chem. 103 (2007) 250265.

15) E.D. Ingall, J.A. Brandes, J.M. Diaz, M.D. de Jonge, D. Paterson, I. McNulty, W. Crawford Elliot and P. Northrup: J. Synchrotron Radiat. 18 (2011) 189-197.

16) S. Sato, D. Solomon, C. Hyland, Q.M. Ketterings and J. Lehmann: Environ. Sci. Technol. 39 (2005) 7485-7491.

17) Y. Hashimoto, A. Takamoto, R. Kikkawa, K. Murakami and N. Yamaguchi: Environ. Sci. Technol. 48 (2014) 5486-5492. 